\title{
As imagens no texto: entre García Márquez e Roberto Bolaño. Da alegoria do tempo ao universo das imagens ${ }^{1}$
}

\section{Carlos Rincón ${ }^{2}$}

\section{Tradução: Ana Isabel Guimarães Borges ${ }^{3}$}

Resumo: A leitura do conto Un señor muy viejo con unas alas enormes, de Gabriel García Márquez, parte da alegoria europeia do tempo e mostra, ao longo da análise do relato sobre a passagem dessa alegoria por um vilarejo do Caribe, que, na memória cultural desse espaço, não há lugar para o conceito de tempo europeu. Aberto, assim, o estudo e passando pela entronização como ícones das efígies oficiais dos pais da pátria, a partir de retratos de Simón Bolívar, e de metaficções como alegorias da nação, de crônicas e pinturas de paisagens, fecha-se o artigo com Cuando éramos inmortales, de Arturo Fontaine, em que é narrada uma aula de história da arte, na qual as revolucionárias obras As meninas, de Diego Velázquez, e Guernica, de Pablo Picasso, são usadas pelo professor ultraconservador para encenar o discurso da história da arte como enunciação de pretensos valores universais católicos. As interseções entre textos-imagens são vistas como tipos de representação e tipos culturais básicos, em que o decisivo parece ser a relação infinita entre a linguagem e a pintura, "o visível e o enunciável" (FOUCAULT, 1990) e "a antinomia de palavra e imagem" como a priori histórico (DELEUZE, 1969), que ampararam o que se denomina "the pictorial turn" (MITCHEL, 1987).

Palavras chave: Imagem. Relação linguagem e pintura. Pictorial turn.

1 Este texto foi publicado pela primeira vez em espanhol, na Revista de Crítica Literaria Latinoamericana, 2002, Año 28, No. 56 (2002), pp. 19-37, pelo Centro de Estudios Literarios “Antonio Cornejo Polar"- CELACP. Publica-se aqui pela primeira vez em português, em tradução de Ana Isabel Guimarães Borges.

2 Carlos Rincón (1937-2018) foi catedrático da Universidade Livre de Berlim e subdiretor do Instituto Central de Estudos Latino-americanos. Cursou seu doutorado na Universidade de Leipzig, em 1965, e recebeu, em 2002, o título de Doutor Honoris Causa pela mesma universidade. Foi pesquisador e professor convidado das universidades de Harvard e Stanford. Dirigiu projetos de pesquisa e realizou estadias de pesquisa e de docência patrocinadas pela Fundação Volkswagen, Fritz Thyssen, Johann Gottfried Herder e pelo Serviço Alemão para o Intercâmbio Científico (DAAD). Além disso, participou em atividades de pesquisa apoiadas pela Paul Getty Foundation. É autor de El cambio en la noción de literatura e Avatares de la memoria cultural en Colombia. Formas simbólicas del Estado, museos y cánon literario.

3 Professora Adjunta de Literatura Espanhola na Universidade Federal Fluminense e tradutora literária. Graduada em Ciências Sociais pela Universidade de Costa Rica e Doutora em Letras Neolatinas (Estudos Literários, Literaturas Hispânicas) pela Universidade Federal do Rio de Janeiro. 
rocedentes do mesmo espaço onde Nike e Victoria desenvolviam seus voos majestosos, complexos de imagens abstratas não completamente diferenciados entre si, ligados a Cronos, o Tempo, ao titã Cronos e ao deus latino Saturno, amalgamaram-se e terminaram concentrando-se em uma personificação alegórica. Das figurações do imaginário medieval (Panofsky 1972) aos quadros dos pintores simbolistas europeus de começos do século XX, a alegoria do tempo é, assim, um homem muito velho com asas enormes. Na exposição L'Empire du Temps. Mythes et creations, apresentada no ano 2000 no Louvre nas celebrações do milênio, a seção Le temps personnifié incluiu imagens dessa alegoria produzidas na Europa ao longo de cinco séculos. Dürer, Bronzino, Rubens a pintaram. Os afrescos de Tiepolo no Palazzo Clerici de Milão (1740) a mostram junto aos deuses olímpicos, descansando em uma nuvem que domina a paisagem celeste. Convertida em Caveira, Posada a coloca sobre uma bici

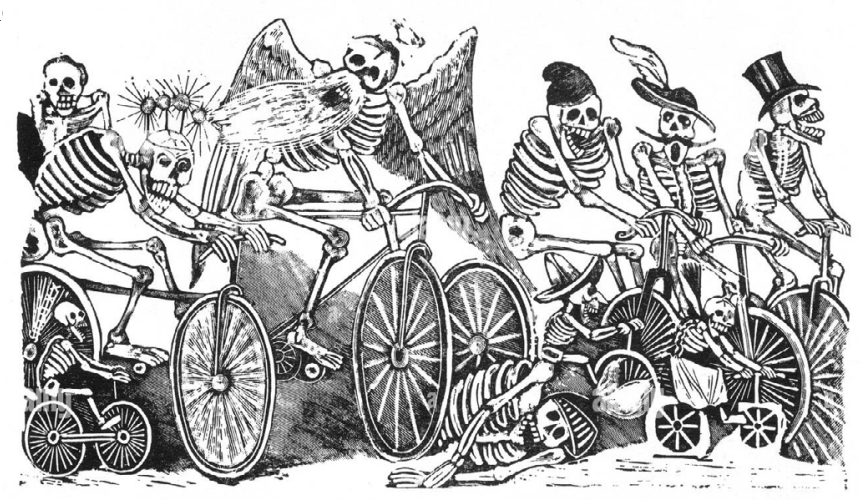

Figura 1 - José G. Posada (1852-1913). Caveira dos jornais.

Museu de Arte Moderna de Nova Iorque. Fundação Larry Aldrich. 
Em um relato sobre sua passagem por um vilarejo do Caribe, a alegoria clássica do Tempo, personificação antimimética que obedece a um código convencional, está colocada em um mundo de significações cuja memória cultural não prevê lugar para ela. "Un señor muy viejo con unas alas enormes" (1969), o conto de García Márquez que relata essa passagem, inscreve-se abertamente dentro da "relación infinita entre el lenguaje y la pintura", entre "lo visible y lo articulable" (FOUCAULT, 1973, p.9). Como experimentação irônica-paródica com a contingência, o culturalmente determinado e a interpretação-reprodução constante de significados do campo visual - "Es un ángel” (GARCÍA MÁRQUEZ, 1972, p.12), diz a moradora -, o relato desenvolve o topos do visitante cuja identidade não é reconhecida, com ajuda de dois processos simultâneos.

O primeiro translada, no eixo da representação, a Alegoria do Tempo do espaço supratemporal das imagens visuais clássicas ao relato mágico-realista. $\mathrm{O}$ segundo situa-se sobre o eixo da comunicação. Trata-se do desconhecimento aporético, ao adotar o narrador a mesma perspectiva dos habitantes do vilarejo caribenho onde se desenvolve a ação, do contrato alegórico que preside a personificação e a decifração clássicas de um homem muito velho com umas asas enormes como Alegoria do Tempo. Correspondem, em um metanível autoirônico, ao que uma das figuras designa como "artificios de Carnaval para confundir a los incautos" (p.14). Por outro lado, os nomes de Pélleas e Melisande, os protagonistas da antiópera de Claude Debussy e do antidrama de Maurice Maeterlinck, exemplos canônicos da estética negativa do modernismo, são castelhanizados e modificados nos de Pelayo e Elisenda. O conto ultrapassa, desse modo, as convenções essencialistas e realistas que presidiram até a literatura moderna a potestade do autor de batizar as figuras, para remeter a questões concernentes a relações autorais, à existência cultural e sociohistórica do escritor, das figuras e dos leitores envolvidos em sua ficção. 
"Un señor muy viejo con unas alas enormes" recapitula autorreflexivamente, de duas maneiras, os mundos culturais e estéticos aos que deve sua existência: 1 . Com o uso da ironia e da paródia como estratégia discursiva, tanto para transladar "magicamente" imagens visuais do perdido saber humanista a um texto narrativo, como para tornar o modernismo estético um objeto de reflexão; 2 . Com o uso da focalização realista-localista de uma "personificação alegórica", de modo que cada um desses dois códigos se coloca em perspectiva, em função de uma coincidentia oppositorum. No ir e vir, em que imagens e palavras se entretecem assim, três dimensões crítico-culturais se destacam. A primeira implica o reconhecimento e a relativização das chamadas tradições e crenças regionais como mediações culturais e estéticas obrigatórias e contingentes. As outras duas podem ser descritas como a sobreposição e a imbricação incrementadas, tornadas perceptíveis, de uma multiplicidade de redes na construção de significados e valores, e a contextualização de relações particulares de classe, gênero e religião dadas, nos modos e processos de legitimação cultural de imagens e textos.

Como "laboratório da narração", onde se experimenta com a estrutura bimedial da representação alegórica, o alcance de "Un señor muy viejo con unas alas enormes" vai além da procura de formas estéticas para construir a figura do sempiterno Patriarca-ditador, que conduziu sua alegorização como produto da mesma formação discursiva que produz a nação como ficção. Essa reatualização antecedeu o redescobrimento da reformulação da alegoria por Walter Benjamin e o posterior diferendo, a propósito do master trope da reflexão poetológica, entre a desconstrução e a hermenêutica, com o que se impôs a reabilitação da alegoria nos estudos literários e culturais (MAN 1979; GREENBLATT 1981). Mas o aspecto que conta aqui é outro: no lapso que media entre o aparecimento desse conto e a edição de El siglo de las luces (CARPENTIER, 1962), a narrativa latino-americana marcou um limiar periodizador e classificatório das 
relações entre texto e imagem dentro dos processos literários no século XX. As inovadoras possibilidades de configuração dessas relações que essa narrativa brindou encontram-se entre os elementos com os quais ficções latino-americanas conseguiram se converter, nas décadas seguintes, em modelos para a ficção pós-moderna e a novelística pós-colonial (MCCAFFERY, 1985, p. XXV-XXVI; SLEMON, 1988; RINCÓN, 1996).

Já desde essa fase, as procuras narrativas sobre as relações e diferenças entre imagens e palavras, a partir dos territórios compartilhados da representação, da referência, da denotação e do significado situaram-se além dos limites da estética do romance moderno tardio e das práticas da neovanguarda. Sua necessidade se impôs na América Latina com a redeterminação da cultura visual como a principal arena de construção das significações culturais, com as conseguintes consequências para o auditivo e o oral, para a espacialização, as dinâmicas psíquicas de espectadores e consumidores e para os regimes de comunicação social. Logo, desde meados dos anos 1970, a centralidade que tivera a literatura, enquanto instituição cultural hegemônica, foi deslocada por uma centralidade distópica, resultado de processos de medialização generalizados, alcançada pela visão e pelo visual. Estes tornam-se determinantes para a vida cotidiana das sociedades e das culturas da América Latina, para a troca de estereótipos identitários de gênero e raça, de relações de poder e na estruturação do político.

O processo descrito esteve acompanhado pela produção de novos saberes acerca do status das imagens nas histórias dessas culturas, desde os períodos de cristianização e ocidentalização e nas reações a elas. Muitas dessas histórias tiveram o selo de uma "guerra das imagens" (GRUZINSKI, 1990), em que, no caso melhor estudado, o do México, foi determinante a tensão entre o ixitla, a "imagem" como atualização de uma força infundida no objeto, e a imagem como representação, estatuída de acordo com as oposições deus-criatura, ser-aparência, essência-reflexo, original-cópia, 
significado-significante, autenticidade-artificialidade (GRUZINSKI, 1988, p. 15-100). Se bem é preciso especificar nos diferentes espaços culturais americanos as formas dessa "guerra das imagens" (CUMMINS, 2001, p. 3-4), trata-se, em geral, de alguma coisa muito diferente das tradições de proibição da imagem nas outras culturas do globo e da iconofobia que caracteriza tantos discursos críticos no Ocidente.

Parecem ser três as principais dinâmicas, dentro do atual universo de imagens, que levaram a recolocar as relações entre o visível e o enunciável como problema estético para a narração:

a) Em uma primeira instância, o interesse pelas novas imagens dos meios eletrônicos e da publicidade, e pelos enigmas da visão, polarizou a atenção. À luz de cruzamentos transdisciplinares inesperados, o divórcio entre imaginário e imaginação da cidade foi objeto de novas abordagens;

b) Em tempos de quebra dos projetos nacionais que vinham se desenvolvendo desde a década de 1920, precipitada pela crise financeira de 1982-83 com a que foi inaugurada a nova fase da globalização na América Latina, o crescimento das indústrias culturais já tinha expandido amplamente a secularização e a internacionalização dos mundos simbólicos. Nessas circunstâncias, o foco do interesse deslocou-se para a transformação da esfera do político, precipitada com a ascensão ao poder de Ronald Reagan, “o primeiro presidente de TV ” (MERRILL, 1988, p. 142), a quem seguiram figuras telegênicas como Fernando Collor, Carlos Salinas e Raúl Menem. O poder dos produtores de imagens e o poder dos ícones (SÁNCHEZ, 1997; MONSIVÁIS, 2000) parece ter sido o que atraiu particularmente os romancistas nesse momento crítico;

c) O desenvolvimento geral dos poderes midiais e teletecnológicos do visível, como realidade cultural dos anos 1990, é o horizonte da mutação que acontece com a geração mais recente de romancistas. Para eles, é determinante a noção de simulacro, colocada a sua disposição com a inversão do platonismo (DELEUZE, 1969), y suas elaborações posteriores 
(BAUDRILLARD, 1981, p. 9-68), no contexto de uma estética concebida como transmidial. Entre as mudanças históricas na extensão cognitiva e linguística do conceito de imagem que condicionam a reabilitação da noção de simulacro, há duas que precisam ser retidas, pois escapam inclusive de tratadistas bem-intencionados, como Régis Debray em Vie et mort de l'image. Une histoire du regard en Occident (1992). Em primeiro lugar, o questionamento da realidade daquilo que se chamou, desde a Ilustração, “imagem mental” (WITTGENSTEIN, 1921). A percepção não é uma comparação analítica entre uma "imagem" na mente de quem percebe e um objeto "real", mas sim um produto sintético do cérebro, que de modo algum se limita ao sentido da vista (MITCHELL, 1987, p. 14-19). Com esse descobrimento, "imagem", como termo que designa produtos da atividade cerebral, recebe um caráter metafórico: transforma-se em imagem. Em segundo lugar, desde os anos 1930 coexistem dois conceitos de imagem, um primordialmente estético (BENJAMIN, 1928) e o outro, político (LIPPMANN, 1922), produzidos pelo desencadeamento das imagens na esfera pública, muito anterior, portanto, ao seu fluir permanente.

Nas duas seções seguintes deste artigo ("Um retrato como híbrido de rastro e aura" e "Os ícones da nação") abordaremos as relações entre ícones fundacionais e metaficções historiográficas, escritas em tempos em que a "comunidade imaginada" (ANDERSON, 1983) perdeu seu caráter de fonte de invenção de autoimagens identitárias no discurso de libertação nacional. As relações imagem-texto como meio para conseguir de-mo(n)strar o mundo antecedente àquele do estado de emergência e do terror estatal são tratadas na seção "As Meninas na época da projeção de diapositivos". Finalmente, a seção "Paisagem da cidade do México uma hora antes de amanhecer" estuda essas relações em seu uso como modelo éticoepistemológico dentro da problemática de uma estética da sobreimpressão, selada pelas procuras do grupo mexica-chileno "infrarrealista ou realvisceralista, segundo o termo com o que sua lembrança é celebrada em Los 
detectives salvajes (BOLAÑO, 1998).

\section{Um retrato como híbridlo de rastro e aura}

Como parte da "invenção de tradições", os estados-nações hispanoamericanos também implementaram, dentro dos seus propósitos partogenésicos, "personificação da 'nação' em simbolo ou imagem" (HOBSBAWN, 1983, p. 7). A entronização como ícones das efígies oficiais dos pais da pátria, a formação de galerias de próceres e pinturas de acontecimentos históricos, o alçamento do mapa a ícone nacional por excelência, o estabelecimento de uma topografia comemorativa como espaço calendárico fazem parte, em torno de 1850-60, dentro da consolidação estatal dos países hispano-americanos, de uma série de processos baseados na produção e manipulação de imagens. Depois de 1870, os resultados desses processos icônicos de formalização do nacional ganharam peso específico no contexto da redefinição, em termos culturais, das nações do continente. Metaficções como El general em seu labirinto (GARCÍA MÁRQUEZ, 1989) e La noche oscura del niño Avilés (RODRÍGUEZ, 1984) são alegorias da nação, que se propõem como tentativas de restitutio in integrum de um verdadeiro rosto ou de documentos autênticos, no momento em que passou a primeiro plano a questão do fracasso das nações latinoamericanas, com seu modelo particular e incompleto do "nationalismo crioulo" (CHATTERJEE, 1986), para constituir-se como tais.

Face to Face to Cyberspace (Basel, 1999), Van Gogh Face to Face (Boston, 2000), Picasso. Figura e Retrato (Tuebingen, 2002) e trabalhos historiográficos dedicados à política das efígies de figuras históricas como Alexandre, o Grande, e Lenin permitem estabilizar duas problemáticas atuais acerca do retrato. A primeira é a sua metamorfose: de ser o lugar onde a personalidade individual aparece, o retrato converteu-se em rosto como superfície projetiva e imagem do interface, passando por retratos em 
que o pintor e seu estilo substituem o retratado. A outra abrange as funções políticas e sociais dos retratos dos soberanos, acopladas à multiplicação por milhares das imagens propagandísticas de governantes.

Para o retrato como lugar onde aparece o indivíduo, foi central a questão da semelhança, tarefa encomendada à memória do artista. $\mathrm{Na}$ sucessão das suas percepções, aquele devia estabelecer as peculiaridades do físico que, fixadas em relação a convenções imperantes, deviam permitir a quem olhasse o retrato confirmar a identidade do retratado. Essa confirmação devia ser alcançada dentro da relação de um eu e um você, na representação do indivíduo com essa única parte de seu corpo (BRILLANT, 1991, p. 23-44). Três décadas após o falecimento de Simón Bolívar, a ausência de retratos que restituíssem suas feições já era parte da lenda das suas desventuras:

Saben nuestros lectores cuan desgraciado fué el Libertador en esto de obtener un retrato con verdadera semejanza á él. La electricidad de sus impresiones, cierto galvanismo de su mirada, una inquietud invencible, cierta voluntariedad de gesto, de actitud y movimiento, todo gentil y caballero, pero de incesante movilidad, hacian imposible sorprender dos veces una misma actitud, ni una misma expresion. Innumerables artistas, americanos y europeos, encontraron su escollo, y hasta su desesperaci6n, en la invencible dificultad de fijar aquella imagen. (GUZMÁN, 1864)

O potencial de revelação que oferecem as lembranças do embandeirado pintor José María Espinosa, nas que refletem sua admiração de soldado e cidadão pelo general Bolívar e o sentido moderno de si que tinha o Libertador dão lugar, no romance de García Márquez, ao tratamento do tema da semelhança na relação entre as imagens que propõem os retratos, a personalidade do retratado e o texto em si. A similitude do retrato constitui, assim, um momento chave da exploração narrativa da 
identidade pessoal de Bolívar realizada no romance.

\section{Memorias de un abanderado:}

Faltaba ya muy poco para la conspiración del 25 de setiembre de 1828 , cuando fue a casa mi tío José I. Paris y me dijo: "El Libertador te manda llamar para que vayas a retratarlo." En el momento preparó un marfil, y nos fuimos a Palacio. Después de presentado a Bolívar, que me hizo un cariñoso recibimiento, se colocó al frente de mí, con los brazos cruzados: apénas empezaba yo el diseño, cuando me dijo: “¿Ya está?" le contesté que faltaba mucho: entonces estiró los brazos, diciéndome: "Puede usted venir cuantas veces quiera, a las once, ántes que se reúna el Consejo." (... ) En ocho días que estuve yendo, no pude aprovechar sino como cuatro horas, porque cuando no estaba inquieto, se quedaba pensativo, con los ojos fijos en el suelo y la cabeza inclinada: asi era que tenía que suspender el trabajo. Un dia se estaba paseando por la sala con el Coronel Wilson; el Coronel Santana estaba leyendo un periódico en inglés; se acercó Bolívar a mi mesa, vió el retrato y dijo: "Santana, ¿sabe usted á quien se parece? á aquel viejo Olaya de La Mesa." Santana fué a ver y al descuido me dijo en voz baja: "No le haga caso que va muy bien, está idéntico." (ESPINOSA, 1971, p. 219)

\section{El general en su laberinto:}

El pintor granadino José María Espinosa lo había pintado en la casa de gobierno de Santa Fe poco antes del atentado de septiembre, y el retrato le pareció tan diferente de la imagen que tenía de sí mismo, que no pudo resistir el impulso de desahogarse con el general Santana, su secretario de entonces. "Sabe usted a quién se parece este retrato?”, le dijo,...”A aquel viejo Olaya, el de La Mesa." Cuando Manuela Sáenz lo supo 
se mostró escandalizada, pues conocía al anciano de La Mesa. "Me parece que usted se está queriendo muy poco", le dijo ella. "Olaya tenía casi ochenta años la última vez que lo vimos, y no podía tenerse en pie." (GARCÍA MÁRQUEZ, 1989, p. 185-186)

A citação da frase que Bolívar teria dito a seu secretário, tomada das Memorias de Espinosa, dá lugar a uma observação do narrador que explica a razão desse primeiro comentário sobre a semelhança do retrato e a duas precisões sobre a relação de Bolívar com sua imagem, que o texto atribui a Manuela Sáenz. A explicação inicial do narrador é inequívoca: "el retrato le pareció tan diferente de la imagen que tenía de sí mismo". De modo que, em relação ao tema do (auto)reconhecimento visual de quem olha um retrato, colocam-se assuntos de maior alcance em relação a Bolívar. Não é só: Como eu gosto de me ver? Como me interessa ser visto? Se o general reconhece no retrato que deveria parecer com ele a presença de outro, a pergunta de parte do leitor é dupla: Quem é esse que o retrato pintado representa e que o texto está retratando?

Por esse caminho, a questão da semelhança remete aos critérios de qualidade e verdade de seus retratos e às funções políticas e sociais que, no exercício do poder, foram associadas às imagens do Libertador. A captação de um suposto núcleo da personalidade como objeto propriamente dito do retrato inclui um assunto político. Esse não é mais do que a restituição ou a censura da aparência física de Bolívar, as particularidades raciais herdadas, próprias da mistura genética plasmada em seu rosto:

El más antiguo de sus retratos era una miniatura anónima pintada en Madrid cuando tenía dieciséis años. A los treinta y dos le hicieron otro en Haití, y los dos eran fieles a su edad y a su índole caribe. Tenía una línea de sangre africana, por un tatarabuelo paterno que tuvo un hijo con una esclava, y era tan evidente en sus facciones que los aristócratas de Lima lo llamaban El Zambo. (GARCÍA MÁRQUEZ, 1989, 
O autor do retrato feito no Haiti em 1816 conhecia as técnicas ensinadas no início do século XIX na França (figura 2). A representação foi a condição da visibilidade especular multiplicada do General. ${ }^{4}$ A substituição da aparência física de Bolívar pela dignidade icônica neoclássica no medalhão de Davi ou o convencionalismo das estátuas de Tenerani - o mesmo vale para o para o retrato de Roulin, convertido em miniatura em Paris em 1828 (figura 3), base, como as estátuas, para óleos, gravuras, medalhas e moedas - equivalem a um tratamento terapêutico de

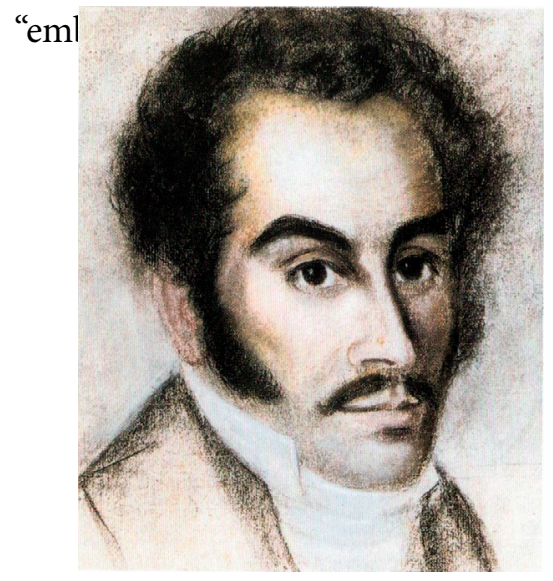

Figura 2 - Artista anônimo. Simón Bolívar.

Haiti: 1816. Coleção Fundação John Boulton, Caracas.

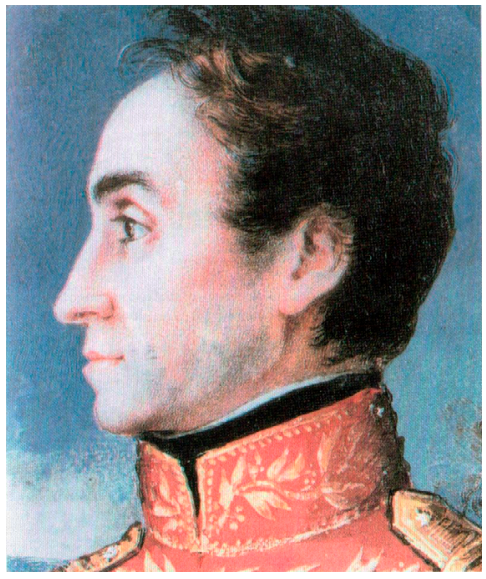

Figura 3 - Artista anônimo. Simón Bolívar.

Paris, c. 1828. Pintado sobre marfim.

Coleção Fundação John Boulton, Caracas.

4 Espinosa também contribuiu para isso. Ele devia viajar para a Itália, tomar "algunas lecciones de uno de los pintores más afamados", e voltar para "poner su escuela", segundo disposições de Bolívar. Mas logo destaca: "El proyecto de mi viaje a Italia iba muy adelantado; ya me soñaba en Roma, lleno de admiración y entusiasmo, viendo y estudiando los prodigios del arte; pero sucedió la conspiración contra la vida del Libertador, y se acabó todo." (ESPINOSA, 1876, p. 260) Em outro momento, agrega: "Por la copia del retrato de Bolívar, que conservo en mi poder, hice después muchos otros para extranjeros y paisanos: el último fue al óleo, de cuerpo entero y tamaño natural." (ESPINOSA, 1876, p. 219-220) 
Os retratos feitos pelo embandeirado-pintor são opostos à elaboração e ao manejo neoclássico da imagem, suas idealizações heroicas monumentalizantes, com função pública de dominação sobre a base de um estereótipo:

Pero a medida que su gloria aumentaba, los pintores iban idealizándolo, lavándole la sangre, mitificándolo, hasta que lo implantaron en la memoria oficial con el perfil romano de sus estatuas. En cambio el retrato de Espinosa no se parecía a nadie más que a él, a los cuarenta y cinco años y ya carcomido por la enfermedad que se empeñó en ocultar y en ocultarse incluso a sí mismo hasta las vísperas de la muerte. (GARCÍA MÁRQUEZ, 1989, p. 186)

Quando Antonio Leocadio Guzmán, editorialista do El Colombiano, viu, em 1864, o retrato de corpo inteiro de Bolívar pintado por Espinosa em base ao esboço de 1828, no momento em que o autentificou como a verdadeira efígie do Libertador, converteu-o em relíquia:

[...] es el Bolívar del año 28: en las vísperas del 25 de septiembre: viéndolo venir sobre sí; la mirada fija, la frente meditabunda, el gesto desengañado, triste y desdeñoso: es Bolívar en el martirio. Pero es él, el mismo: y queremos que todo el mundo lo sepa, y que lo conserve la tradición, y que ella y la Historia lo digan a la Posterioridad.

A los treinta y tantos años hemos vuelto a verle: ese retrato es cuanto pudiera quedarnos de la imagen de Bolívar. (GUZMÁN, 1864, apud ESPINOSA, 1876)

O Libertador morreu no dia 17 de dezembro de 1830. O tipo e a intensidade das reações do espectador frente à série de retratos de 
Bolívar desenhados por Espinosa durante os primeiros meses desse ano não correspondem às expectativas em relação aos ícones da história política. Esses comovedores retratos íntimos de um grande homem em um momento de extrema deterioração física e fracasso político, ao colapsar a Grande Colômbia, o ente estatal no qual tinha depositado seu projeto de estadista (figura 4), têm a conotação de relíquias, ao mesmo tempo em que se fixam na lembrança. A certeza da identidade pessoal está restituída no olhar do retrato, de modo que a percepção desse olhar faz voltar à presença a personalidade assolapada nas aparências do desenho (figura 5). A semifrontalidade convencional do retrato e o dramatismo intenso da relação do soldado-pintor com o general dão lugar a uma presença que responde ao olhar do observador para interpelá-lo (figura 6).

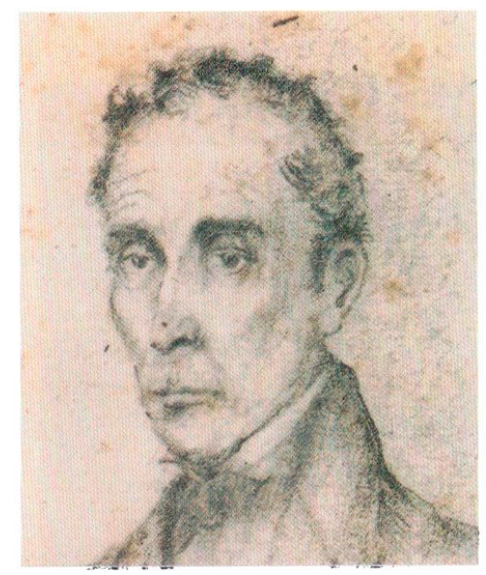

Figura 4 - José María Espinosa. Simón Bolivar. Bogotá, 1830. Grafite sobre papel. Coleção Fundação John Boulton, Caracas.

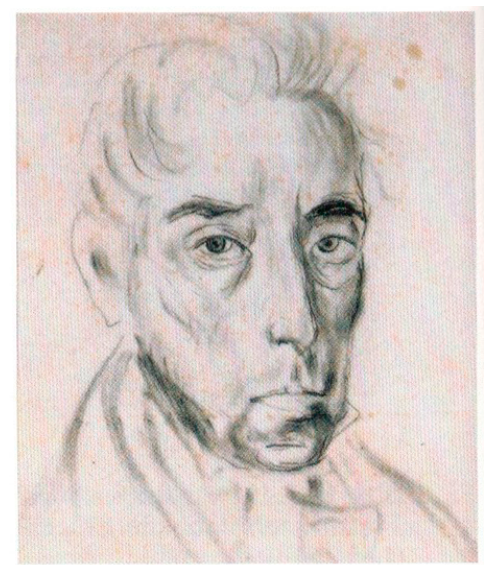

Figura 5 - José María Espinosa. Simón Bolívar. Bogotá, 1830. Lápis carvão e grafite sobre papel. Coleção Sylvia Boulton, Caracas.

A Verônica marca um momento de importância na história de Ocidente, como parte da pré-história do retrato e de uma tecnologia da 
gravura e da impressão. Segundo a lenda medieval da verdadeira efígie, do vera icon, Verônica limpou com um pano o rosto ensanguentado e coberto de suor de Jesus e, nesse pano, suas feições ficaram impressas. Híbrido de rastro e aura, no qual por graça divina a proximidade e a longitude se fundem, o vera icon é produto não criado por mão humana, acheropoieton, como a fotografia. Conserva os rasgos do Deus encarnado para fazê-los aparecer em uma presença inteligível

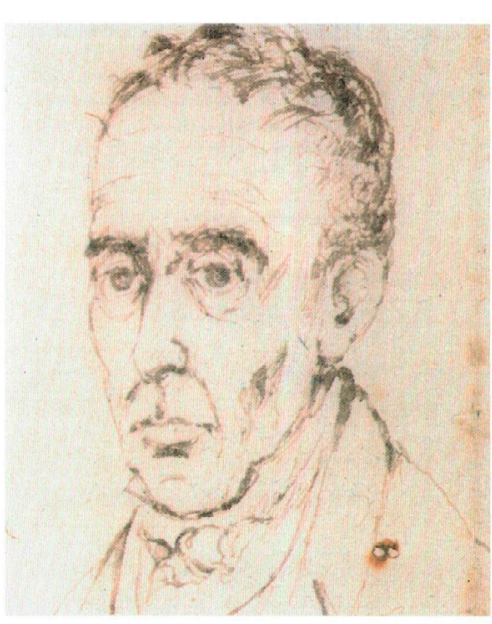

Figura 4 - José María Espinosa. Simón Bolívar. Bogotá, 1830. Grafite sobre papel. Coleção Fundação John Boulton, Caracas.

e inexpressável. Une assim, ao

momento retrospectivo, um prospectivo, uma espera: é garante da facie ad faciem com Deus sob as condições da ótica terrena, quer dizer, in speculum et in enigmate (WOLF, 2001; KESSLER/WOLF, 1998).

Rasgo essencial da relíquia é ser resto, como parte de um todo que só através da narração pode ser completado. Ao fazer da doença, que destrói o corpo do Libertador, metáfora da dissolução do corpo do exército libertador, o desmembramento do corpo político da Grande Colômbia e o malogro de seu projeto continental, O general em seu labirinto é o analogon textual dos retratos-relíquias desenhados pelo embandeirado-pintor. Legitimado pela transmissão, entre os retratos de Espinosa e o texto, de um poder energético de visão e visibilidade, o romance de García Márquez encontra o fundamento do seu propósito político na qualidade de vera icon que reclama para si. 
A monografia que Edgardo Rodriguez Juliá dedicou ao pintor José Campeche abre-se com uma comprovação e uma tese:

Antes de la literatura fue la pintura. La obra de Campeche le provee a nuestra nacionalidad una imagen que se adelanta al testimonio literario, tenemos que esperar hasta mediados del XIX para que nuestra cultura se convierte en verbo. (...) La oculta nostalgia de Campeche tiene su fundamento en el porvenir, en una esperanza cifrada en la culminación venidera de la nacionalidad criolla. (RODRÍGUEZ, 1986, p. 7)

La noche oscura del niño Avilés é um pastiche visionário da retórica das imagens pictóricas e dos modos narrativos e linguísticos das crônicas do século XVIII, que traça a história da cidade de Nueva Venecia. O corpo, a libido, o desejo e a ordem da metáfora servem como base para que o romance possa ser simultaneamente re-visão de pinturas que testemunham a modernidade da sociedade que representam e re-escritura de documentos históricos inexistentes. Entre uma e outra operação, media uma pintura imaginada. A metaficção historiográfica adquire, assim, na sua relação com uma arte pictórica que não percebe mais o ideal geral mas está situada no limite de declarar ideal a obra particular, a função de restituir imaginariamente passados inventados redescobertos e plurais. Seus signos são o multirracial em conflito e o multilinguístico.

As convenções do manuscrit trouvé, the Prophetic Pictures e da edição de documentos de arquivo servem para situar as origens da nação em uma temporalidade mítica. O prólogo de um historiador, assinado em "San Juan Bautista de Puerto Rico", com data de "9 de octubre de 1946", propõe uma primeira descrição das relações entre os documentos editados a continuação e uma pintura alegórica narrativa: 
La crónica de González Campos pertenece a una colección de documentos descubierta por el archivero Don José Pedreira Murillo en el 1913. Cuando Pedreira leyó la descripción de la colonia lacustre, recordó haber visto en un rincón del Archivo Municipal de San Juan -"entre olvidadas estibas de folios y arrumbados caballetes", según sus palabras- un tríptico que representaba "extraño paisaje de canales e islotes donde se alzan majestuosos edificios parecidos a colmenas". De este modo, el olvidado tríptico de Silvestre Andino, genial sobrino de José Campeche, cobra un nuevo y relevante significado. El retablo narra, sirviéndose de oscuras visiones simbólicas y paisajes realistas del más minucioso detallismo, verdaderas miniaturas, la historia del singular poblado y su fundador, el Niño Avilés. Pero aquí no termina la relación entre los documentos y las miniaturas; aquellos son, en su mayor parte, detalladas descripciones y comentarios de éstas: mientras la palabra complementa la imagen, descifrando visiones y animando paisajes, el pincel de Andino ha pretendido contarnos el mito de la ciudad maldita. (RODRÍGUEZ, 1984, p. 10)

Os dados bibliográficos da primeira nota de pé de página, com função de autenticação científica, correspondem a um livro que não existe. A segunda informa que "José Campeche fue el primer pintor puertorriqueño. Nace en 1751 y muere en 1809" (idem, ibidem). Entretanto, o que foi afirmado inicialmente sobre a relação crônicas-tríptico no estilo de Bosch/ Breughel é imediatamente relativizado. As crônicas seriam exercícios retóricos com os dispositivos da ekphrasis, conjunto de tableaux de langage fantasmatizados ao redor do tríptico alegórico: "Algunos historiadores no le conceden valor histórico a los documentos de la colección Pedreira. Se trata, según ellos, de una 'historia apócrifa' compuesta en torno a los T visionarios del genial pintor" (idem, ibidem).

Os "documentos editados" são uma montagem de narrativas 
fragmentadas e sucessivas, abertas e estruturadas entre si, contínuas e permanentemente interrompidas, em cuja leitura as experiências da repetição, da diferença e da pluralidade substituem os pressupostos de unidade, origem e fim. Ao mundo de seus referentes refratados pertencem, entre outras pinturas de Campeche, a cidade espreitada do extenso panorama, com caráter de ex-voto pátrio, Sitio de San Juan Bautista de Puerto Rico por los ingleses en el año 1797, a iconografia dos governantes eclesiásticos, como o Bispo de Trespalacios e Verdeja, a salvação milagrosa de um naufrágio de Ramón Power y Giralt. Igualmente, o autorretrato em trajes de jíbaro de Luis Paret Alcázar, professor do pintor desterrado a Porto Rico por Carlos III.

Entretanto, é outro quadro, onde se cancela "el diálogo entre el emblema y el gesto" (RODRÍGUEZ, 1986, p. 123), o retrato do menino Juan Pantalón Avilés de Luna y Alvarado (figura 7), nascido sem braços nem pernas, o que tem maior transcendência para o romance. Foi o último que Campeche pintou. Sua interpretação alegórica o situa no cruzamento entre três problemáticas: o fetichismo, o nascimento do monstro

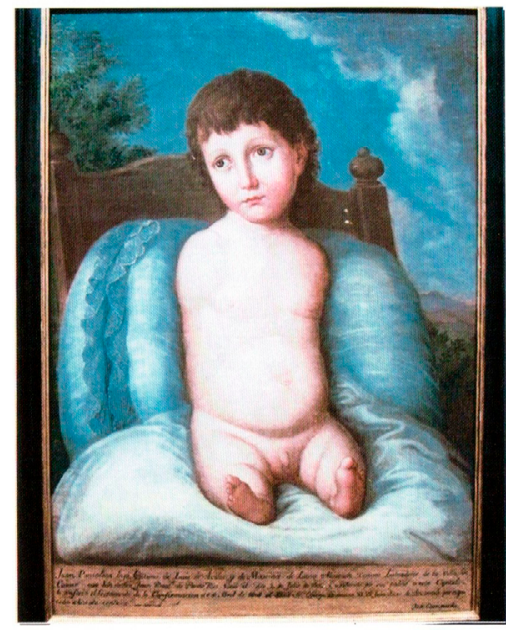

Figura 7 - José Campeche. Retrato do menino Juan Pantaleón Avilés de Luna y Alvarado. e a autoridade do ícone. O menino Avilés tem, na trama do romance, a função de um fetiche. No transcurso que levou de Charles de Brosses ao debate desenvolvido em Documents, o fetichismo passou de ser uma metalinguagem colonial da Ilustração para o pensamento do Outro africano e caribenho, a servir de base para uma teoria do valor no campo da arte, em oposição tanto à tese de Freud 
sobre a sublimação enquanto fonte de arte quanto à iconofobia cristã que reduziu o fetichismo ao campo do olhar (RINCÓN, 2001). William Pietz define-o como uma retórica identificadora, a cujos juízos de valor ligam objetos sociais territorializados e encarnações pessoais individuais, dentro de "a serie de fixaçoes singulares históricas" (PIETZ, 1985, p. 739-40). Convertido na encarnação da "verdade", fonte sacralizada de legitimidade e autoridade política, o menino monstruoso é "talismã" do poder. Alguma coisa assim como a entidade "povo" no discurso populista e na prefiguração do fetichismo do Estado.

Em relação à problemática do nascimento do deforme, no limiar do século XIX, o monstro ainda não é um acidente genético, um fenômeno científico abordável a partir da teoria biológica, mas também não é mais a manifestação de um desejo inconfessado e inconfessável, de uma "violent aberration on the mother's part", pois, dentro da tradição aristotélica, a imaginação materna era a única responsável por "the reproduction of the species as formal species" (HUET, 1983, p. 73). No horizonte da epistemologia moderna, a presença do pai do monstro foi recuperada desde Frankenstein (idem, p. 76). De acordo com a interpretação de Rodríguez Juliá na sua monografia, o olhar de senex et puer do menino Avilés estaria dividido entre "la obediencia y la rebeldía, la salvación y la maldición, la santidad y nuestra soberbia”. Preso em si, já que "atado en su cuerpo", seria "metáfora del sufrimiento" das castas e dos subalternos na sociedade colonial (RODRÍGUEZ, 1986, p. 118). A questão da genealogia e da autoridade do ícone como modelo do menino monstruoso resolvem-se na configuração entre imagem, texto e decifração que o romance propõe. Como alegoria, cujo duplo caráter se situa entre a figura e o tropo, a revisão e a releitura irônicas praticadas pelo texto o convertem na "verdadeira" história - os documentos autênticos - das origens da nação porto-riquenha. 
As analogias dinásticas ou familiaristas às que recorrem jovens romancistas dentro da sua autocompreensão - a relação avós-netos, as heranças transmitidas na linha pais-filhos menores (VOLPI, 2002) -, tentam dar conta de processos históricos literários e culturais nos quais o determinante, junto ao fato de serem complementares e adjacentes no mercado, está constituído pela descontinuidade de concepções e pela paragênese. Essa mudança já era visível em escritores que, em 1980, tinham seus vinte e cinco anos. Seus romances foram escritos depois da crise das ordens simbólicas que embargou as sociedades da América Latina nas últimas décadas e da experiência da sua arbitrariedade e relatividade no exílio e na emigração. A desterritorialização do valor e do afeto, a abstração que diluiu muitas das especificidades sociais e culturais, nas quais podiam se refugiar, até há pouco, as comunidades e sociedades latino-americanas às que puderam pertencer, estes são os pressupostos básicos do trabalho dos narradores mais jovens. Algo paralelo acontece com as artes e a viagem (BENÍTEZ, 1999). Histórias sobre a obsolescência dos mundos e dos imaginários onde se educaram, memórias mitológicas da era em que agora vivem, formaram parte da agenda dessas duas gerações de escritores.

Em Cuando éramos inmortales (1998), de Arturo Fontaine, a narração da dissolução da ordem social de uma infância mostra com telescópio as violências que haveriam de desintegrar coesões sociais, esboços de vida e identidades societais forjadas no Chile na segunda metade do século XX. O título faz alusão não apenas à infância e à doutrina cristã da ressurreição. $\mathrm{O}$ assunto tratado no capítulo central do livro, com o relato de duas horas de aula de história da arte em um colégio de religiosos em Santiago nos anos 1960, dadas pelo "Padre Ramírez", não é a questão moderna do uso das imagens: seu emprego como instrumentos de doutrinação ou de manipulação, para fazer incorporar os contratos sociais e sexuais que distinguem as posições de identidade em uma sociedade hierárquica 
como a chilena. Também não se trata de que tipo de identidades estavam sendo inculcadas, através de que tipo de representações nem a quem elas eram ensinadas, em um colégio religioso. O romance apresenta duas fases da situação pedagógica na sala de aula, nas que a arte é uma questão de visão de mundo. Na primeira, a pintura de Velázquez serve como pretexto para um discurso propedêutico generalizador sobre sua catolicidade, no qual identidade, imaginário e poder são vinculados para traçar limites religiosos e culturais excludentes. Esse ritual exorcista da secularização moderna não obedece apenas à agressiva idiossincrasia intolerante e etnofóbica de um sacerdote espanhol, nem sua significação se reduz a autorizar discriminações e violências entre alunos, que conduzem a um suicídio. A demarcação constante de limites fundamenta e exibe como lei o poder representado. Vista a posteriori, é um antecedente autorizador de futuras violências.

Tomando como objeto Guernica e, sem mencionar o título, As Meninas, a segunda fase encena o discurso da história da arte como enunciação de pretensos valores universais católicos, na época da projeção escolar de diapositivos. Esse discurso faz a arte moderna recobrar o espaço temporal que tem na narrativa da história social europeia, para aniquilá-lo ante os alunos com uma sentença condenatória, pois essa arte teria tentado ocupar o lugar de Deus. Os conhecimentos que devem poder repetir no dia da prova são resumidos pelo padre Ramires em um apotegma: "La historia del arte tiene una dirección, un sentido (...) el sentido de la historia del arte moderno es la historia de la pérdida del sentido de la vida”. (FONTAINE, 1998, p. 234-35). A análise que faz da obra mais famosa do século XX não parte dos tópicos tradicionais sobre ela: o tema político, a concentração na dor e na destruição, o mito vanguardista de que nesse quadro a própria arte acusaria em nome da humanidade, devolvendo-lhe um papel político que há muito tempo tinha perdido (ZEILLER, 1996). A comoção que se apoderou de cada uma das figuras para convertê-las em testemunho de 
uma realidade concreta atroz e da violência anônima da modernidade, dilui-se em uma enumeração e uma tese:

Observen, jóvenes, estos dibujos: la contorsión imposible del caballo, el horror de las bocas con sus dientes desordenados, la crispación absurda en las manos. Este espanto es nuestro propio espanto. Es la desfiguración del mundo, ¿no es cierto? Fragmentación, disolución, desintegración de la materia. Son los efectos de la bomba, sí. Pero hay algo más. (FONTAINE, 1998, p. 235- 236)

$\mathrm{Na}$ sala de aula, não são usados os dois projetores consagrados. $\mathrm{O}$ diapositivo também não pode dar conta do tamanho gigantesco, aparentado com o do mural público, que situa Guernica fora do cânone dos quadros de museu. Contudo, podia restituir suas cores, a luta do branco e do preto, da luz e das trevas, com cinza noturno iluminado por uma lâmpada e alumiado pelo branco deslumbrante de uma figura de mulher que, como verdade personificada, faz do quadro uma chamada moral para o espectador. A violência que preside a relação pedagógica ignora a utilização das cores que fazem o quadro.

-Padre, ¿el cuadro es así o está borrado? ¿O es blanco y negro la diapositiva? - irrumpe Girardi.

Risas.

-Quiero decir: ¿está terminado, padre, o quedó inconcluso como esas estatuas de Miguel Ángel que vimos el otro día?

-Girardi, Girardi... Usted primero piensa y piensa; y luego hace la pregunta tonta.

Nuevas risas.

-Hay algo más, les digo, hay algo más. Nosotros hemos despedazado el mundo. Si. Pero, ¿qué mundo? (FONTAINE, 1998, p. 236)

Como culminação da demonstração tendenciosa, As Meninas são 
o pretexto para uma apologia que responde a essa pergunta. O que se discute nesses anos sobre o quadro não é tampouco objeto de ensino: sua autorreflexividade de metapintura, as questões do poder político e o poder representacional, do Poder do Soberano e o poder da pintura e do pintor. O saber transmitido reduz-se a observações sobre a anedota, as qualidades formais e a um lugar comum tradicional (KESSER, 1994, p. 168-169): o quadro fixaria o instante da visão criadora. A estratégia intelectual do texto coloca na boca do docente, ao falar do quadro, um rosário de equívocos sobre a construção da perspectiva, o ponto de fuga, o horizonte, a procedência da imagem refletida no espelho, a autorreflexividade do quadro:

Pero volvamos al cuadro: hay aquí una sensación de movimiento súbitamente detenido, ¿verdad? El pintor, por ejemplo, interrumpe su labor. ¿Y por qué? ¿Qué detiene y deja suspensas las miradas? El espejo del fondo lo revela: la llegada de los reyes es el imán. ¿Y por qué? Hay un cuadro famoso de Tiziano que se llama La religión socorrida por España. ¿Comprenden? Todo poder humano se ordena al rey, y el rey se ordena a Dios. Esta imago mundi Velázquez nos la hace sentir al atrapar- nos al interior del cuadro, ¿comprenden? ¿Y saben cuál es el secreto? Esta es una sociedad con estamentos. Ni siquiera se pretende que el mérito establezca las jerarquías. La mentira de la igualdad de oportunidades que repite y repite la angustiada burguesía liberal se desconocía en esa época. Nada más cruel que hacerle creer a la gente que los de arriba están en ese lugar por merecimientos individuales. ¡Qué hipocresía! (FONTAINE, 1998, p. 237- 238)

Precisamente La Variation sur Les Meninas de Picasso conservou de maneira rigorosa a forma de composição geral de As Meninas (SNYDEN \& COHEN, 1980), que o expositor altera. Mais do que nenhuma outra 
circunstância na vida do protagonista, do que qualquer outro momento na vida do colégio, são as aulas de história da arte sobre essas duas pinturas emblemáticas as que conseguem dotar estruturalmente o romance de um capítulo em que aparece re-presentado seu mundo.

\section{Paisagem da cidade do México uma hora antes de amanhecer}

A substituição no papel de criadores ou orientadores de opinião dos intelectuais públicos pelas figuras da mídia é um fenômeno observado na generalidade dos países latino-americanos. Todavia, sobre o pano de fundo desse processo, Nocturno de Chile (2000) não se reduz a fazer uma autocrítica dos intelectuais. A esfera literária e artística do Chile, as práticas dominantes, marginais ou na periferia do marginal, como as neovanguardistas da autoproclamada cena (Beat Generation) avançada (vanguarda histórica), dissolvida em 1981-82, são o material que tornam o livro de Roberto Bolaño um espaço estético de escrutínio ético e cultural.

A forma como o romance consegue seu propósito faz dele um exemplo cabal do recurso às estratégias de apropriação, suscetíveis de algo de muito maior alcance: ultrapassar, dentro de uma procura estética metonímica e hipertextual, que vai e vem entre a mimese e o simulacro, o que tem sido descrito como a impossibilidade de representação linguística e conceitual do trauma (CARUTH, 1995).

Como re-elaboração do topos moderno do monólogo no leito de morte: "Ahora me muero, pero tengo muchas cosas por decir" (BOLAÑO, 2000, p. 11), o monólogo febril do romance é o produto degradado da memória autobiográfica, que, em outros casos, é a forma mais alta de recordação humana, de um clérigo espanhol com funções de instância superior de juízo crítico, dentro do pequeno mundo público das letras chilenas. É uma alusão direta ao sacerdote José Miguel Ibáñez Langlois. Membro do Opus Dei, foi crítico literário do El Mercurio - mais tarde órgão 
oficioso do governo ditatorial do general Augusto Pinochet - desde 1966, com o desarmante pseudônimo de Ignacio Valente. Sob essas circunstâncias políticas, sociais e culturais, o padre Ibánez foi, durante duas décadas, o Papa da crítica nesse país (CÁNOVAS, 1990, p. 171-174).

Entre muitos outros acontecimentos, o monólogo do sacerdotecrítico arrasta a recordação de uma anedota pessoal contada anos atrás por um vácuo escritor-diplomata, a propósito das visitas que fez em Paris, nas vésperas ou já iniciada a Segunda Guerra, ao ateliê de um pintor guatemalteco, onde teria se encontrado também com Ernest Jünger. Contava que o pintor, presa da melancolia e "como si quisiera dejarse morir" de fome, durante essas visitas, vivia "contemplando desde su ventana el plano urbano de París" (BOLAÑO, 2000, p. 41). O relato da lembrança incluía a descrição de uma pintura, em tom de connaisseur santiaguense:

Y cuando don Salvador traspuso el umbral de la vivienda del centroamericano lo primero que vio fue a Jünger embutido en su uniforme de oficial de la Wehrmacht, abstraído en el estudio de un cuadro de dos metros por dos, un óleo que don Salvador había visto innumerables veces, y que llevaba el curioso título de Paisaje de Ciudad de México una hora antes del amanecer, un cuadro de insoslayable influencia surrealista, movimiento al cual el guatemalteco se había adscrito con más voluntad que éxito, sin gozar jamás de la bendición oficial de los celebrantes de la orden de Breton, y en el cual se advertía una cierta lectura marginal de algunos paisajistas italianos así como una querencia, muy propia por otra parte de centroamericanos extravagantes e hipersensibles, de los simbolistas franceses, Redon o Moreau. El cuadro mostraba la Ciudad de México vista desde una colina o tal vez desde el balc6n de un edificio alto. Predominaban los verdes y los grises. Algunos barrios parecían olas. Otros barrios parecían negativos de fotografías. No se percibían figuras humanas pero sí, aquí y allá, esqueletos difuminados que podían ser 
tanto de personas como de animales. (BOLAÑO, 2000, p. 43-44)

O sacerdote recorda o efeito retórico com que concluía a narração da anedota, a pretendida disjunção entre as expectativas criadas nos ouvintes pela descrição do quadro, e o efeito piegas da interpretação final:

atisbó o creyó atisbar una parte de la verdad, y en esa parte mínima de la verdad el guatemalteco estaba en París y la guerra había empezado o estaba a punto de empezar y el guatemalteco ya había adquirido la costumbre de pasar largas horas muertas (o agónicas) delante de su única ventana contemplando el panorama de París, y de esa contemplación había surgido el Paisaje de Ciudad de México una hora antes del amanecer, de la contemplación insomne de París por parte del guatemalteco, y a su modo el cuadro era un altar de sacrificios humanos, y a su modo el cuadro era un gesto de soberano hastío, y a su modo el cuadro era la aceptación de una derrota, no la derrota de París ni la derrota de la cultura europea briosamente dispuesta a incinerarse a sí misma ni la derrota política de unos ideales que el pintor vagamente compartía, sino la derrota de él mismo, un guatemalteco sin fama ni fortuna pero dispuesto a labrarse un nombre en los cenáculos de la Ciudad Luz, y la lucidez con que el guatemalteco aceptaba su derrota, una lucidez que infería otras cosas que trascendían lo puramente particular y anecdótico, hizo que a nuestro diplomático se le erizasen los vellos de los brazos o que, como dice el vulgo, se le pusiera la carne de gallina. (BOLAÑO, 2000, p. 47-48)

O relevante aqui é a inflexão que adota a apropriação como conjunto de procedimentos que, junto com a alegoria, caracterizam tendências principais da atividade cultural contemporânea. $\mathrm{O}$ texto se apropria de Anos da ocupação (1954), de lembranças dispersas sobre César Vallejo, 
das páginas onde André Malraux recorda em 1974 uma visita de 1937 ao ateliê de Picasso, enquanto o pintor trabalhava em Guernica, que não representa o bombardeio da cidade pela Legião Condor. Ademais, entre o princípio da classificação alfabética do Manual de zoologia fantástica (1957), de Jorge Luis Borges e Margarita Guerrero, e o da ficha-retratobibliográfico-histórico-literário (BERGER, 2001) de La literatura nazi en América (BOLAÑO, 1996), havia mediado, mais do que a ficha corrida, a apropriação dos princípios das biografias imaginárias do escritor Luis Álvarez Petraña (1934-1970) e do pintor Jusep Torres Campalans (1958), de Max Aub (JENNERJAHN, 2002, p. 81-87). O pintor de Aub e as pinturas de Max Ernst, de Chirico, levam à intensidade da experiência, entre observação e visão, da pintura do guatemalteco. ${ }^{5}$ Em seu quadro, aquilo que é dado com a aparência ilusionista de um espaço tridimensional e uma organização arquitetônica é a cidade (Paris) como trans(des)aparecer em um aparecer (México), como (in)visibilidade da imagem original para além da visibilidade da imagem estatuída, na simultaneidade das formas reconhecíveis.

A apropriação coloca, assim, em questão diversas categorias representação, propriedades objetivantes do olhar, observador, contexto da visão - e desloca as relações espaço-temporais que definiram tradicionalmente a equação corpo-percepção, ao tempo em que convida a revisar a narrativa moderna da história da arte do século XX desde a perspectiva do regime do simulacro. Com uma revisão desse tipo, a pintura abstrata, sua rejeição da semelhança, resulta "muito menos subversivo face a mimesis tradicional e a estética transcendental do que é usual no entanto"

5 Existem paralelos e pontos coincidentes com a longa descrição da gravura Vue générale de Barcelona en Histoire (1967), de Claude Simon, onde o começo semi-geográfico se quebra para dar lugar a uma visão trágica, subjetiva e antecipadora do narrador: "une ville vouée, consacrée a l'avance (...) à la violence, aussi irrémédiablement qu'un certain dosage de salpêtre et de charbon mélangé et comprimé dans un tube d'acier est destiné à exploser" (Histoire. Paris: Minuit, 1967, p. 175). O tom e o registro são, apesar de tudo, completamente diferentes. Por outro lado, "l'observatoire élevé (...) où sétait placé l'artiste" (p. 176)" é imaginário: não existe nenhuma colina do lado da cidade de onde ela está sendo representada. Essa perspectiva é, isso sim, a de Nueva York vista desde la terraza (1937), de Rufino Tamayo, e a de Ciudad de México (1942), de Juan O’Gorman. 
(FOSTER, 1993, p. 96). O surrealismo pictórico dos anos 1919 a 1945, pelo contrário, com a sua ênfase no trabalho sobre o imaginário, registro visual e pré-verbal por definição, aparece em seu antieurocentrismo como o momento mais radical no processo de arte no Ocidente no século XX.

$O$ episódio recordado de maneira degradada no romance, em suas relações entre imagem e texto, exige que o leitor compare, para decidir em que se assemelham ou não, quatro realidades que se superpõem: a) A imagem de Paris que o pintor teria visto desde sua janela; b) A Veduta do México que está pintando; c) A percepção de Paris na sua realidade de cidade ocupada e massacrada, na pintura do México como cidade de sacrifícios, segundo a interpretação do banal embaixador-escritor; d) $\mathrm{O}$ romance que está lendo. As semelhanças não se devem aqui às coisas comparadas, mas sim aos critérios de comparação, não dados por si, ao mesmo tempo em que a comparação reclama, para poder realizar-se e sobreimprimir seus componentes, outra instância. Pede uma memória que, na observação de cada uma das coisas comparadas, teria que reter as demais. Daí os alcances epistemológicos e éticos da apropriação, da tarefa comparativa que postula e das transferências que propicia e exige. Pois apenas na medida em que se realiza operativamente consegue conformarse como memória. Tem assim a capacidade de descondicionar as relações entre o passado e o futuro, de implementar a consciência do contingente e de responder a outra interrogante: em que medida o texto contribui para determinar ou expor problemáticas reprimidas e para propiciar o confronto do que é com o imperativo ético de um dever ser.

\section{Referências}

ANDERSON, B. Imagined Communities: Reflections on the Origin and Spread of Nationalism. London, New York: Verso, 1983.

BAUDRILLARD, J. Simulacres et simulation. Paris: Editions Galilee, 1981. 
BENJAMIN, W. Ursprung des deutschen Trauerspiels (1928), In:

Gesammelte Schriften, ed. R. Tiedemann, H. Schweppenhausser, T. 1. 1. Frankfurt am Main: Suhrkamp Verlag, 1980, p. 203-430.

BENITEZ D., I. "Guía de viaje. Nomadismo e identidad en el arte contemporáneo”. Cuadernos de arena, número 65, p. 4-15, 1999.

BERGER, T. „Roberto Bolaño: Die Naziliteratur in Amerika“. Parapluie, o.D., número 7. Inverno 1999/2000. Disponível em: http: //www. parapluie. de/archiv/sprung/aufgelesen.html Acesso em: 20.01.2002.

BOLAÑO, R. Nocturno de Chile. Barcelona: Editorial Anagrama, 2000. . Los detectives salvajes. Barcelona: Anagrama, 1998.

BORGES, J.L.; GUERRERO, M. Manual de zoologia fantástica (1957). México D.F.: FCE, 1984.

BRILlANT, R. Portraiture. Cambridge, Mass.: Harvard University Press 1991.

CÁNOVAS, R. "Hacia una histórica relación sentimental de la crítica literaria en estos reinos". Cuadernos hispanoamericanos, n. 482-483, p. 161176, ago/sept. 1990.

CARPENTIER, A. El siglo de las luces. Madrid: Espasa-Calpe, 1962.

CARUTH, Cathy. Trauma: Explorations in Memory. Baltimore, London: 1995.

CHATTERJEE, Partha. Nationalism Thought and the Colonial World: A Derivate Discourse. Tokio, London: Zed Books for United Nations University, 1986.

CUMMINS, T. "Latin American Art: Politics, History, and Aesthetics". David Rockefeller Center for Latin American Studies Newsletter, Winter/ Spring 2001.

DELEUZE, G. Logique du Sens. Paris: Editions de Minuit 1969. . Foucault. Paris: Editions de Minuit 1986.

DEBRAY, Régis. Vie et mort de l'image. Une histoire du regard en Occident. 
Paris: Editions Gallimard, 1992.

ESPINOSA, José María. Memorias de un abanderado. Recuerdos de la patria boba 1810-1819 (1876). Bogotá: Biblioteca Banco Popular, 1971.

FONTAINE, Arturo. Cuando éramos inmortales. Madrid-México-Santiago: Alfaguara, 1998.

FOSTER, Hall. Compulsive Beauty. Cambridge, Mass.: MIT Press, 1993.

FOUCAULT, Michel. The Order of Things: An Archeology of the Human Sciences. New York: Random House, 1973.

FOUCAULT, M. Les mots et les choses. Une archéologie des sciences humaines. Paris: Gallimard, 1990.

GARCIA Márquez, G. "Un señor muy viejo con unas alas enormes”. In: . La increíble y triste historia de la cándida Eréndira y de su abuela desalmada. México D.F.: Editorial Hermes, S.A., 1972.

. El general en su laberinto. Madrid: Mondadori Espania S.A., 1989.

GRUZINSKI, S. La colonisation de l'imaginaire. Sociétés indigenes et occidentalisation dans le Mexique espagnol XVIe - XVIIIe siècle. Paris: Editions Gallimard, 1988.

. La guerre des images. De Christophe Colomb et Blade Runner (1492-2019). Paris: Fayard, 1990.

GREENBLATT, S., Ed. Allegory and Representation. Baltimore: 1981.

GUZMÁN, A. “Retrato de Bolívar (1864)”. In: J.M. Espinosa, Memorias de un abanderado: recuerdos de la patria boba, 1810-1819 (1876). Bogotá: Biblioteca Banco Popular, 1971.

HUET, M-H. "Living Images: Monstruosity and Representation". Representations, n. 4, 1983, p. 73-87.

JENNERJAHN, I. „Literatur, Kunst und Kultur in Chile seit den 1960er Jahren im Spiegel der Fiktion Roberto Bolafio La literatura nazi en América“. Magister Artium Arbeit. Lateinamerika-Institut der Freien Universitat-Berlin, 2002. 
KESSER, C. Las Meninas von Velazquez. Eine Wirkungs- und Rezeptionsgeschichte. Berlin: Reimen Verlag, 1994.

KESSLER, H. L./WOLF, G. (eds). The Holy Face and the Paradox of Representation. Bologna: Nuova Alfa 1998.

LIPPMANN, W. Public Opinion. London: G.Allen \& Unwin, 1922.

MAN, P. de. Allegories of Reading: Figural Language in Rousseau, Nietzsche, Rilke, and Proust. New Haven: Yale University Press 1979.

MCCAFFERY, L. Postmodern Fiction. A Bio-Bibliographical Guide. New York, Westport, Connecticut, London: Greenwood, 1985.

MERRIL, R. "Simulations: Politics, TV, and History in the Reagan Era". In: R. Merrill (ed). Ethics/Aesthetics: Post-Modern Positions. Washington: Maisonneuve Press, 1988.

MITCHELL, W.J.T. Iconology. Image, Text, Ideology. Chicago, London: The University of Chicago Press, 1987.

MONSIVAIS, C. Aires de familia, Barcelona: Anagrama, 2000.

PANOFSKY, E. "Father Time”. In: Studies in Iconology. Humanistic Themes in the Art of the Renaissance (1939), 2a. ed., New York: Evanston, Harpen \& Row Publishers, 1962.

PIETZ, W. The Problem of the Fetish, I". I, Res. Anthropology and Aesthetics, n. 9, p. 5-17, 1985.

PASAMONTE, J. de. "La vida de un sacerdote del Opus Dei, novelada por Roberto Bolaño”. La Vanguardia, Barcelona, 23-XI-2000.

RINCÓN, C. "Postmodernismo, discursos postcoloniales y los nexos cartográficos del realismo mágico". In: . Mapas y pliegues. Ensayos de cartografía cultural y de lectura del neobarroco. Santafé de Bogotá: Tercer Mundo Editores, 1996.

. „Magisch/Magie“. In: K. Barck, M. Fontius et allii (Ed.), Historisches Worterbuch Asthetische Grundbegriffe, T.3. Stuttgart-Weimar: J.B. Metzler, 2001. 
RODRÍGUEZ J., E. La noche oscura del Niño Avilés. Río Piedras: Ediciones Huracán, 1984.

. Campeche o los diablejos de la melancolía. San Juan de Puerto Rico: Instituto de Cultura Puertorriqueña, 1986.

SÁNCHEZ, Luis Rafael. No llores por nosotros. Puerto Rico, Hanover: Ediciones del Norte, 1997.

SNYDER, J.; COHEN, T. "Reflexions on Las Meninas: Paradox Lost”. In: Critical Inquiry 7, 1980, 9.

SLEMON, S. "Magic Realism as Post-Colonial Discourse". Canadian Literature, 116, 1988, p. 9-24.

VOLPI, J. Diálogo con Jorge Volpi. Por David Hernández, 03-IV-2002/ www.librusa.com/entrevistavolpi.htm

WITTGENSTEIN, L. Tractatus Logico-Philosophicus (1921). In:

Schriften 1, Frankfurt am Mai: Suhrkamp Verlag, 1980.

WOLF, G. Schleier und Spiegel. Tradition des Christusbildes und die Bildkonzepte der Renaissance. München: Wilhelm Finck Verlag, 2001.

ZEILLER, A. Guernica und das Publikum. Picassos Bild im Widerstreit der Meinungen. Berlin: Reimer Verlag, 1996.

Las imágenes en el texto: entre García Márquez y Roberto Bolaño. De la alegoría del tiempo al universo de las imágenes

Resumen: La lectura del cuento Un señor muy viejo con unas alas enormes, de Gabriel García Márquez, parte de la alegoría europea del tiempo y muestra, a lo largo del análisis del relato sobre el paso de esa alegoría por un poblado del Caribe, que en la memoria cultural de ese espacio no hay lugar para el concepto europeo del tiempo. Abierto así el estudio y pasando por la entronización como iconos de las efigies oficiales de los padres de la patria, a partir de retratos de Simón Bolivar, y de metaficciones como alegorías de la nación; de crónicas y pinturas de paisajes, se cierra el artículo con el análisis de Cuando éramos inmortales, de Arturo Fontaine, donde se narra una clase de historia del arte, en la que las revolucionarias obras Las Meninas, 
de Diego Velázquez, y Guernica, de Pablo Picasso, son usadas por el ultraconservador profesor para poner en escena el discurso de la historia del arte como enunciación de presuntos valores universales católicos. Las intersecciones entre textos e imágenes se ven como tipos de representación y tipos culturales básicos, donde lo decisivo parece ser la "relación infinita entre el lenguaje y la pintura", "lo visible y lo articulable" (FOUCAULT, 1990) y "la antinomia de palabra e imagen" como a priori histórico (DELEUZE, 1969), que auparon lo que se denomina "the pictorial turn" (MITCHELL, 1987).

Palabras clave: Imagen. Relación imagen-pintura. Pictorial turn.

Images in the text: between Garcia Marquez and Roberto Bolaño from the allegory of time to the universe of images

Abstract: The reading of Gabriel García Márquez' short story, Un señor muy viejo con unas alas enormes, starts by focusing the European allegory of time and shows throughout the analysis of the story - which narrates the voyage of this allegory to a Caribbean village - that this European concept of time does not fit in the cultural memory in this location. Thus, opening the study and passing through the enthronement as icons of the official effigies of the fathers of the country, from portraits of Simón Bolivar, and the metafictions as allegories of the nation, as well as chronicles and paintings of landscapes, the article is closed by addressing Arturo Fontaine's Cuando éramos inmortales. This narrative about a lesson of art history where the revolutionary works, Diego Velázquez' Las meninas and Pablo Picasso's Guernica, are used by the ultraconservative professor to fake the discourse of art history in order to enunciate so-called universal catholic values. The intersections of texts-images are seen as types of representation and basic cultural types where the decisive moment of constitution seems to be the "infinite relation between language and painting", "visible and enunciable" (FOUCAULT, 1990), "the antinomy of word and image" as a priori historical (DELEUZE, 1969). These theoretical reflections raised up what has been denominated "the pictorial turn" (MITCHELL, 1987).

Keywords: Image. Relations between language and painting. "Pictorial turn".

Recebido em: 08/09/2021

Aceito em: 17/09/2021 